\title{
The incidence of anxiety in patients with chronic subjective tinnitus
}

\author{
Ljiljana Krsmanović1,3, \\ Siniša Šolaja ${ }^{1,3}$, \\ Nenad Arsovićc,3, \\ Bojan Joksimović ${ }^{3}$, \\ Zoran Dudvarski ${ }^{2,3}$ \\ Gabrijela Šolaja ${ }^{4}$
}

'University Hospital Foca, Department of Otorhinolaryngology and

Maxillofacial Surgery, The Republic of Srpska, Bosnia and Herzegovina

${ }^{2}$ Clinical Center of Serbia, Clinic for Otorhinolaryngology and Maxillofacial Surgery Belgrade, Serbia

${ }^{3}$ University of East Sarajevo, Faculty of Medicine, Foca, The Republic of Srpska, Bosnia and Herzegovina

${ }^{4}$ University Hospital Foca, Department of Neurology, Foca, The Republic of Srpska, Bosnia and Herzegovina

Primljen - Received: 14/03/2021

Prihvaćen - Accepted: 01/04/2021

\section{Corresponding author:}

Ljiljana Krsmanović, MD

Mlade Bosne 4, 73300 Foča

ljiljanakrsmanovic85@gmail.com

Copyright: @2021 Ljijjana Krsmanović et all. This is an Open Access article distributed under the terms of the Creative Commons Attribution 4.0 International (CC BY 4.0) license.

\section{Summary}

Introduction. Tinnitus is a perception of a sound in the ears in the absence of acoustic stimulation whose pathophysiological mechanisms have not been evaluated yet. Approximately, $1-2 \%$ of people report distress which can negatively affect their daily performance. Our study aimed to assess the incidence of anxiety in patients with tinnitus.

Methods. The study was designed as a cross-sectional study. The participants were divided into two groups: a group of 73 patients with tinnitus (with two subgroups in relation to the duration of tinnitus - less than one year and more than one year) and a control group of 43 patients without tinnitus. We examined the presence of anxiety in all patients using the Burns Anxiety Inventory (BAI). The quality of life of all patients was estimated by Tinnitus Handicap Inventory (THI).

Results. In the group of patients with tinnitus, $56.2 \%$ of them had mild and $24.7 \%$ moderate hearing loss, while $27.7 \%$ of respondents from control group had mild and $8.5 \%$ moderate levels of hearing impairment. THI results showed that patients with tinnitus less than 1 year had a significantly $(p=0.002)$ higher level of disorders in daily life, compared with the group who had tinnitus for more than 1 year. The $30.8 \%$ of respondents had minimal anxiety, 26.7\% borderline anxiety, $17.5 \%$ mild anxiety, the same percentage of respondents moderate, $5 \%$ severe, while $2.5 \%$ had extreme anxiety based on BAI.

Conclusion. Anxiety can be considered as potentially significant modulators of changes in brain structures observed in people with tinnitus.

Key word: tinnitus, anxiety, Tinnitus Handicap Inventory, Burns Anxiety Inventory

\section{Introduction}

Although a lot of progress in medicine has been made during last decades, tinnitus still remains a clinical puzzle and scientific enigma. Tinnitus is the perception of sound, or ringing in the ears (originated from the Latin word "tinnire" - to ring), in the absence of acoustic stimulation [1,2]. It was classified into objective tinnitus or somatosounds like "pulsatile tinnitus" (when specific 
sound source is present) and subjective tinnitus as "non-pulsatile tinnitus" (the absence of a specific sound source) $[2,3]$. It was estimated that the tinnitus affects 8 to $25.3 \%$ of the population of the United States and among 5 to $15 \%$ of the general population and economic burden of health care of 7.5 billion dollars in some developed parts of the world [1,4]. Also, it has been known as multifactorial and heterogeneous disorder, most commonly defined as a phantom auditory sensation without an audible external source [5]. Like a persistent tinnitus, it is a symptom, rather than a disease entity, experienced by $10-15 \%$ of the population [6] and at least $7.5 \%$ of children and adolescents $[5,7]$.

Approximately, one-third to half adults report a moderate annoyance, even though $1-2 \%$ report significant distress and disability which can negatively affect his/her daily performance or lead to insomnia, anxiety, depression, hearing problems, and usually can be associated with cognitive disorders (or data cognitive processing difficulty) $[5,6]$. As well as that, every fifth person in population has an emotional disability, while $0.5 \%$ of population are unable to lead a normal life [3]. Although there are people who compensate well the chronic, subjective tinnitus, depressive and anxiety disorders have been observed as typical emotional factors that are considered to be strong predictors of poor adaptation to tinnitus $[1,3]$.

Pathophysiological mechanisms of tinnitus have not been evaluated yet. If we cut the auditory nerve, sound perceptions can still persist. This means that tinnitus is not just a reflection of cochlear damage. In addition to this, the results of previous studies Eggermont and Roberts [8], conducted only on animals, showed that the nervous changes can cause hearing loss correlated with clinical symptoms in humans. However, these assumptions have not been confirmed yet, as an increased rate of damage to the central neurons of the auditory tract has been observed, as one of more neural reasons for tinnitus [8].
Even though it is sometimes difficult to estimate the relationship between the duration of tinnitus and the intensity of symptoms with quality of life, our study aimed to assess the incidence of anxiety in patients with chronic subjective tinnitus and whether the severity of tinnitus and the degree of anxiety were related.

\section{Methods}

The research was designed as a cross-sectional study conducted from June to December 2011. Patients were divided into two groups. The first group consisted of 73 patients with unilateral or bilateral tinnitus who were at the first or control examination at the Department of Otorhinolaryngology and Maxillofacial Surgery - University Hospital Foca (21 of them) and the Clinic for Otorhinolaryngology and Maxillofacial Surgery of the Clinical Center of Serbia (52 of them). The second group consisted of patients who did not have tinnitus (control group) - 47 employees at the Faculty of Medicine in Foca and who met the general criteria for participation in the study. In the group of patients with tinnitus we classified respondents into two subgroups - patients who had tinnitus for less than one year and patients with tinnitus for more than one year. Also, we examined the presence of anxiety in all patients as well as its correlation with tinnitus.

The general criteria for inclusion of all respondents in the study were: 20-75 years of age, ability to answer the questions asked and consent to be included in the research. Exclusion criteria from the study were acute or chronic inflammatory diseases of the external and middle ear, patients who have occasional tinnitus and the presence of tinnitus in proven CNS disease (multiple sclerosis, tumors, etc.).

The examination was performed using the usual methods of approaching patients with tinnitus: anamnesis, clinical examination of 
the ear (including otomicroscopy), nose and throat, functional examination of hearing, other examinations resulting from the above examinations. Tinnitus questions were standard for all patients who were examined.

Tonal liminal audiometry was performed by standard procedure on a SIBELMED AC50-B clinical apparatus in an acoustically isolated cabin, where the hearing threshold was determined for frequencies 250, 500, 1,000, 2,000, 4,000, 6,000 Hz for bone and air conduction.

All patients completed a specific questionnaire to assess quality of life in patients with tinnitus (Tinnitus Handicap Inventory THI). It is one of the most used instruments worldwide, developed by Newman, Jacobson, and Spritzer in 1966 [9]. The instrument is composed of 25 questions divided into 3 subgroups: functional (11 items), emotional (9 items) and catastrophic (5 items) [10]. The THI evaluates how tinnitus interferes in daily activities and to quantify handicap in people who have tinnitus. It is a validated subjective self-administered test that aims to determine the degree of distress suffered by the tinnitus patient. Originally, the questionnaire is in English. According to the internationally accepted methodology for translation, validation and cultural adaptation of the HRQoL assessment questionnaire, a standard, "back translation" methodology was used to develop the Serbian version of the questionnaire $[11,12]$.

Both groups of subjects, with and without tinnitus, completed the Burns Anxiety Inventory (BAI). This is one of the most common questionnaires for anxiety estimation widely used, easily understood by patients, which has been translated into more than 40 languages. The questionnaire consists of a list of thirty-three symptoms related to anxiety. They are divided into three categories: physical symptoms (16 items), anxious thoughts (11 items) and anxious feelings (6 items) [13]. The results of this questionnaire numerically show the general anxiety symptoms with which we assess the severity of anxiety (minimal, borderline, mild, moderate, severe and extreme anxiety), but also the success of treatment $[14,15]$.

Data analysis was performed using the Software Package for Statistical Analysis The IBM SPSS 21 (Chicago, IL, 2012). The $\chi 2$ square test of the nonparametric statistical tests was used, and of the parametric tests, the $\mathrm{T}$ test of independent samples was used. The correlation was done with the help of Pearson's correlation coefficient. Arithmetic means and standard deviations were used to display average values. The p-values of less than 0.05 were considered as statistically significant. The results were shown as figures and tables.

\section{Results}

The study involved $73(60.8 \%)$ respondents diagnosed with tinnitus and $47(39.2 \%)$ respondents without tinnitus. There were no significant differences between groups of respondents when it comes to gender and age. However, statistically significant difference was found in terms of level of hearing impairment ( $p=0.007)$, where majority of respondents from group with tinnitus had mild (56.2\%) and moderate hearing loss $(24.7 \%)$, while only $27.7 \%$ of respondents from group without tinnitus had mild and $8.5 \%$ had moderate level of hearing loss. Statistically significant difference $(p=0.001)$ in type of audiometric curve was also found between two groups of respondents. Respondents without tinnitus significantly more often $(68.1 \%)$ had straight audiometric curve in comparison to respondents with diagnosed tinnitus $(28.8 \%)$, which is expected given that in this group majority of patients had normal hearing (59.6\%) when compared to group with tinnitus $(9.6 \%)$ (Table 1$)$.

We examined the quality of life of patients with diagnosed tinnitus with Tinnitus Handicap Inventory, which measures 
Table 1. Comparison of socio-demographic characteristics, level of hearing impairment and type of audiometric curve between groups of respondents

\begin{tabular}{|c|c|c|c|c|}
\hline Groups & & $\begin{array}{l}\text { Group } \\
\text { with tinnitus, \% } \\
\text { or } \mathrm{M} \pm \mathrm{SD}\end{array}$ & $\begin{array}{c}\text { Group } \\
\text { without tinnitus, } \\
\% \text { or } M \pm S D\end{array}$ & $\mathrm{p}$ \\
\hline \multirow{2}{*}{ Gender } & Male & 53.4 & 44.4 & \multirow[t]{2}{*}{$0.153^{*}$} \\
\hline & Female & 46.6 & 59.6 & \\
\hline Age, years & & $54.3 \pm 14.7$ & $50.2 \pm 8.8$ & $0.381^{* *}$ \\
\hline $\begin{array}{l}\text { Level of hearing } \\
\text { impairment }\end{array}$ & $\begin{array}{l}\text { Normal hearing } \\
\text { Mild HL } \\
\text { Moderate HL } \\
\text { Severe HL } \\
\text { Profound HL }\end{array}$ & $\begin{array}{c}9.6 \\
56.2 \\
24.7 \\
\times 6.8 \\
2.7\end{array}$ & $\begin{array}{l}59.6 \\
27.7 \\
8.5 \\
2.1 \\
2.1\end{array}$ & $0.007^{*}$ \\
\hline Type of audiometric curve & $\begin{array}{l}\text { Upward } \\
\text { Straight } \\
\text { Downward }\end{array}$ & $\begin{array}{l}2.7 \\
28.8 \\
68.5\end{array}$ & $\begin{array}{l}2.1 \\
68.1 \\
29.8\end{array}$ & $0.001^{*}$ \\
\hline $\begin{array}{c}\text { Total, } \\
\text { number (\%) }\end{array}$ & & $73(60.8)$ & $47(39.2)$ & \\
\hline
\end{tabular}

${ }^{*}$ Chi-square test, ${ }^{* *}$ student $\mathrm{t}$ test; $\mathrm{M}$ - mean, SD - standard deviation; HL - hearing loss

Table 2. Comparison of level of tinnitus handicap with duration, frequency and intensity of tinnitus

\begin{tabular}{|c|c|c|c|c|c|c|c|}
\hline $\begin{array}{c}\text { Level of Tinnitus } \\
\text { Handicap }\end{array}$ & & Slight & Mild & $\begin{array}{c}\text { Moderate } \\
\%\end{array}$ & Severe & Catastrophic & $\mathrm{p}$ \\
\hline Duration of tinnitus & $\begin{array}{l}\leq 1 \text { year } \\
>1 \text { year }\end{array}$ & $\begin{array}{c}7.3 \\
71.9\end{array}$ & $\begin{array}{c}24.4 \\
6.3\end{array}$ & $\begin{array}{l}46.3 \\
12.5\end{array}$ & $\begin{array}{c}17.1 \\
0.7\end{array}$ & $\begin{array}{l}4.9 \\
9.4\end{array}$ & $0.002^{*}$ \\
\hline Frequency of tinnitus & $\begin{array}{l}\text { Low } \\
\text { Moderate } \\
\text { High }\end{array}$ & $\begin{array}{c}0 \\
37.5 \\
36.5\end{array}$ & $\begin{array}{c}0 \\
37.5 \\
14.3\end{array}$ & $\begin{array}{c}50 \\
25 \\
31.7\end{array}$ & $\begin{array}{c}50 \\
0 \\
9.5\end{array}$ & $\begin{array}{c}0 \\
0 \\
7.9\end{array}$ & $0.132^{* *}$ \\
\hline Intensity of tinnitus & $\begin{array}{l}\text { Low } \\
\text { Moderate } \\
\text { High }\end{array}$ & $\begin{array}{l}44.4 \\
35.4 \\
14.3\end{array}$ & $\begin{array}{c}5.6 \\
22.9 \\
0\end{array}$ & $\begin{array}{l}27.8 \\
29.2 \\
57.1\end{array}$ & $\begin{array}{c}16.7 \\
8.3 \\
0\end{array}$ & $\begin{array}{c}5.6 \\
4.2 \\
28.6\end{array}$ & $0.432^{*}$ \\
\hline $\begin{array}{l}\text { Total, } \\
\text { number (\%) }\end{array}$ & & $26(35.6)$ & $12(16.4)$ & $\begin{array}{c}23 \\
(31.5)\end{array}$ & $\begin{array}{c}7 \\
(9.6)\end{array}$ & $\begin{array}{c}5 \\
(6.8)\end{array}$ & \\
\hline
\end{tabular}

${ }^{*}$ Chi-square test, ${ }^{* *}$ Fisher test; \#student $\mathrm{t}$ test; $\mathrm{M}$ - mean, SD - standard deviation; HL - hearing loss. 
the interference of tinnitus of respondents on their daily activities and quality of daily life. Majority of respondents (35.6\%) had slight disturbance because they had tinnitus, $16.4 \%$ had mild, $31.5 \%$ had moderate, $9.6 \%$ had severe, while $6.8 \%$ of respondents had disturbed sleep patterns and difficulty with any daily activities. We categorized patients in terms of duration of tinnitus into two groups, tinnitus present within a year, and tinnitus present more than one year. Respondents who had tinnitus less than one year had significantly $(\mathrm{p}=0.002)$ higher level of disturbances in daily life, where mild, moderate and severe disturbances were more often present, when compared to group that had tinnitus that lasted more than one year. Statistically significant difference between groups divided by tinnitus handicap score was not found when it comes to level of frequency and intensity of tinnitus (Table 2).

The Burns Anxiety Inventory was used to assess the level of anxiety among respondents, both, in group with and without tinnitus. The majority of respondents had minimal anxiety (30.8\%), 26.7\% had borderline anxiety, 17.5\% had mild level of anxiety, the same percentage of respondents had moderate level, 5\% had sever anxiety, while $2.5 \%$ of respondents had extreme anxiety or panic. Chi-square test showed that between groups with and without anxiety high statistically significant difference was found $(\chi 2=7.318 ; p=0.001)$ when it comes to level of anxiety among respondents. Borderline (28.8\%:23.4\%), mild (17.8\%:17\%), moderate $(23.3 \%: 8.5 \%)$, severe $(6.8 \%: 21 \%)$ and extreme anxiety $(4.1 \%: 0 \%)$ were significantly frequent in the group with tinnitus when compared to the group without tinnitus (Figure 1).

We tested correlation between used tests in our research (Tinnitus Handicap Inventory and Burns Anxiety Inventory). A strong and positive statistically significant correlation $(\mathrm{r}=0.617 ; \mathrm{p}=0.0001)$ was found between quality of life tested by THI and level of anxiety tested by BAI, which means that respondents who felt handicapped in everyday life

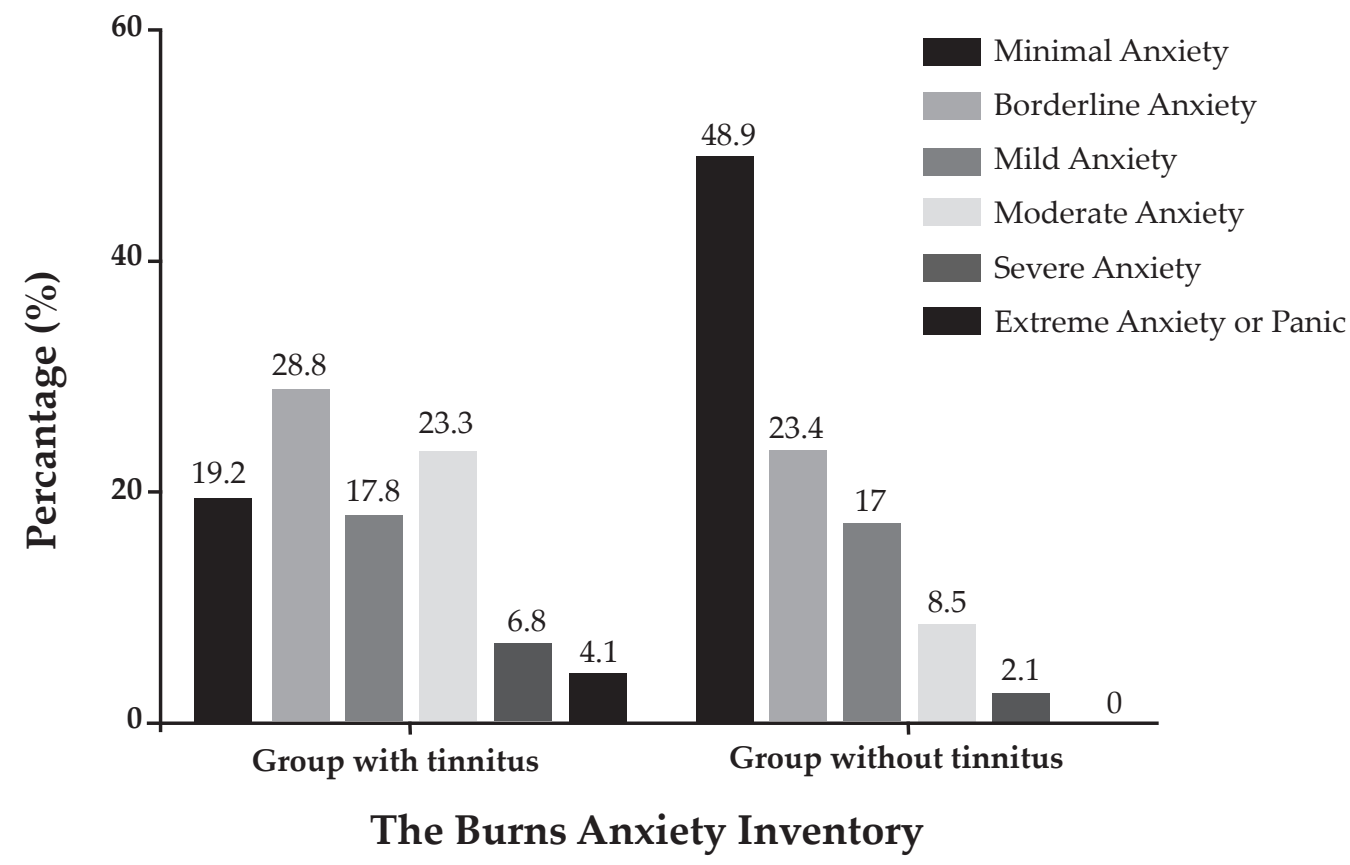

Figure 1. Level of Anxiety measured by the Burns Anxiety Inventory in respondents with and without tinnitus 
because of effects of tinnitus also had higher level of anxiety (Table 3).

Table 3. Correlations between the Tinnitus Handicap Inventory and Burns Anxiety Inventory

\begin{tabular}{ccc}
\hline & $\begin{array}{c}\text { Tinnitus } \\
\text { Handicap } \\
\text { Inventory }\end{array}$ & $\begin{array}{c}\text { Burns } \\
\text { Anxiety } \\
\text { Inventory }\end{array}$ \\
\hline $\begin{array}{c}\text { Tinnitus } \\
\text { Handicap } \\
\text { Inventory } \\
\text { Burns } \\
\text { Anxiety } \\
\text { Inventory }\end{array}$ & $0.617^{*}$ & \\
\hline
\end{tabular}

Pearson's correlation test was used, significance level 0.05 , r2 values are presented in the table * $-\mathrm{p}<0.001$

When we divided patients with tinnitus into groups according to duration of tinnitus we found significant difference $(p=0.001)$ between groups when it comes to level of anxiety measured by The Burns Anxiety Inventory. Patients who had tinnitus for less than one year also had higher level of mild, moderate, severe and extreme level of anxiety, when compared to the patients who had tinnitus for more than one year (Table 4 ).

\section{Discussion}

Although tinnitus, as a phenomenon of sound perception in the absence of external auditory stimulus, is a common symptom in individuals of heterogeneous age groups, it is not still known whether the presence of tinnitus in patients leads to changes in the quality of life and mental disorder, or whether it is influenced by intensity and frequency of tinnitus as well as its duration, age, sex and degree of hearing impairment [14]. Potential reasons for tinnitus are variable disorders in several parts of the central and peripheral auditory tract and the brain. Recent studies have shown a close connection between tinnitus and mental disorders with an increase in the
Table 4. Comparison of level of anxiety measured by the Burns Anxiety Inventory with duration of tinnitus

\begin{tabular}{lccc}
\hline \multicolumn{1}{c}{$\begin{array}{c}\text { Duration of } \\
\text { tinnitus }\end{array}$} & $\mathbf{1}$ year & $>\mathbf{1}$ year & $\mathbf{p}$ \\
\hline $\begin{array}{l}\text { Level of anxiety } \\
\text { measured by BAI } \\
\text { Minimal anxiety }\end{array}$ & 7.3 & 34.4 & $\mathbf{0 . 0 0 1 ^ { * }}$ \\
$\begin{array}{l}\text { Borderline } \\
\text { anxiety }\end{array}$ & 17.1 & 43.8 & \\
$\begin{array}{l}\text { Mild anxiety } \\
\text { Moderate } \\
\text { anxiety }\end{array}$ & 26.8 & 6.2 & \\
$\begin{array}{l}\text { Severe anxiety } \\
\text { Extreme anxiety }\end{array}$ & 94.1 & 9.4 & \\
\hline $\begin{array}{l}\text { Total, number } \\
\text { (\%) }\end{array}$ & 4.9 & 3.1 & \\
\hline
\end{tabular}

*Chi-square test, BAI (The Burns Anxiety Inventory)

rate of comorbidity - depression, loss of libido and self-confidence with the appearance of anxiety [1].

In our study involved 73 (60.8\%) respondents diagnosed with tinnitus and 47 (39.2\%) respondents without tinnitus. We did not find significant differences between the groups of respondents when it comes to gender and age. However, some authors report that increase with age is one of the factors that determines the presence of tinnitus, and it is relatively more common in the individuals over 40 [14-16] while others describe predominance among men (16-18). Reasons for this are thought to be numerous, including study design, sample size, socio-demographic characteristics, ethnicity, work environment, short-term exposure to noise, stress, being a soldier, systemic and metabolic diseases like osteoarthritis, thyroid disease, rheumatoid arthritis, hyperlipidemia etc. $[15,16]$. On the other hand, in terms of level of hearing impairment, statistically significant difference has been found. The majority of respondents from the group with tinnitus had mild (56.2\%) 
and moderate hearing loss $(24.7 \%)$, while only $27.7 \%$ of respondents from the group without tinnitus had mild and $8.5 \%$ had moderate level of hearing loss. Also, the respondents without tinnitus significantly more often had normal hearing (straight audiometric curve in $68.1 \%$ ) in comparison to respondents with diagnosed tinnitus (28.8\%), which is expected given that in this group majority of patients had normal hearing $(59.6 \%)$ when compared to the group with tinnitus (9.6\%).

Also, we estimated the incidence of anxiety and the degree of association with tinnitus in a patient with chronic subjective tinnitus. We used the BAI to assess the degree of anxiety, and to estimate discomfort caused by tinnitus, the THI questionnaire has been used. Our results have shown that patients which had tinnitus for less than one year had significantly higher level of disturbances in daily life, where mild, moderate and severe disturbances were more often present, when compared to the group which had tinnitus that lasted more than one year. Statistically significant difference between groups divided by tinnitus handicap score was not found when it comes to level of frequency and intensity of tinnitus. The score of the THI is consistent with the reports of other authors who used the same questionnaire to evaluate the burden of patients with tinnitus $[19,20]$. In relation to the control group by the results of THI test, which coincides with the reports of other authors, we concluded that very severe and severe tinnitus reduce working ability, disrupt sleep, cause emotional disorders and significantly affect the quality of life in general [20]. In the group with tinnitus according to the results of BAI, the largest number of subjects had borderline anxiety, $28.8 \%$, moderate anxiety was found in $23.3 \%$ of subjects, mild anxiety was found in $17.8 \%$, severe anxiety $6.8 \%$ and 3 subjects had extreme anxiety or $4.1 \%$. The results of our study have shown that there is a statistically highly significant difference in the TAS between the group with tinnitus and the group without it, which indicates that the presence of noise has had an impact on the difficulties examined by this test.

Even though the auditory cortex is not thought to be directly related to anxiety disorders, changes in the activity of the major central neurotransmitter gamma-Aminobutyric acid (GABA) indirectly affect the mechanism of anxiety disorder. However, Shulman et al., then Lockwood et al. have connected the tinnitus to hyperreactivity of the subcortical structures [3]. Due to the influence of stress, noise and other environmental factors, glucocorticosteroid and mineralocorticoid hormones were secreted in order to maintain homeostasis and defend the organism from harmful influences. Released hormones, by binding to their receptors, indicate changes in the auditory pathway. There are numerous controversies about stress-induced neuroplasticity as one of the causes of tinnitus, but strong evidence in the literature, as explained by Mazurek et al., still does not exist $[1,21]$. However, Shulman et al., then Lockwood et al. connected the tinnitus to hyperreactivity of the limbic system and subcortical structures [3]. A directly related structure of the dorsal nuclear complex, with parts of the brainstem that do not belong to the auditory network, but have an impact on emotions and their control have been proven. In general, that hyperactivity of certain parts of the brainstem, especially the two subcortical structures - the locus ceruleus and the raphe nucleus, is directly related to anxiety disorder as the cause of tinnitus [21].

Also, a statistically highly significant difference in the scores of the BAI was proved between subjects in whom the noise lasted less than one year and subjects in whom the noise lasted more than one year, which means that respondents who felt handicapped in everyday life because of effects of tinnitus also had higher level of anxiety. As well as that, we found strong and positive statistically significant correlation between quality of life tested 
by the THI questionnaire and the Burns anxiety questionnaire. These correlations have been reported in other studies [22]. Furthermore, there are many cross-sectional studies in the literature that have explained the association between tinnitus and anxiety disorders, but also one longitudinal study by Sheue-Jane Hou et al. [15]. They assessed the incidence of tinnitus in patients with and without the presence of anxiety and, through several explanations, indicated a positive correlation between tinnitus and mental disorders. Some of those explanations were, that in people who have tinnitus, anxiety disorder occurs first, as well as that tinnitus and anxiety are causally related. In addition, dysfunction of the central nervous system or genetic factors results in both diseases. This means that the hypothalamus, the limbic system, the locus coreuleus, the dorsal cochlear nucleus and the hypothalamic-pituitary-adrenal axis, as structures which are not under the control of our consciousness, are thought to be important parts of puzzle involved in the pathogenetic mechanisms of anxiety and tinnitus $[1,15]$.

The results of our study indicate that anxiety is a possible cause of tinnitus, but due to the still insufficiently clear mechanisms, it is difficult to determine whether the tinnitus or a psychiatric disorder first occurred. A significant increase in the presence of tinnitus was observed in older women with anxiety disorders, as well as the fact that the anxiety is more often present in people in whom tinnitus lasts longer and greatly negatively affects the quality of life.

Funding source. The authors received no specific funding for this work.

Ethical approval. The Ethics Committee of the Faculty of Medicine in Foca approved the study and informed consent
Explaining the mechanisms of occurrence and the cause-effect relationship between tinnitus and mental disorders require more thorough research in the field of neurobiology and genetics. One of the main criteria, in order to establish pharmacological and cognitive-behavioral therapeutic approaches in people with chronic subjective tinnitus, is their personal experience of discomfort and burden of the disease. Associated with mental comorbidities, such as insomnia, irritability, anxiety or depression, have only an additional negative impact on the quality of life.

We consider that a limitation of our study is the small size of control group in comparison to the size of group with tinnitus, which can have an impact on the outcome of anxiety.

\section{Conclusion}

Anxiety and other mental disorders can be considered as potentially significant modulators of changes in brain structures observed in people with tinnitus. Since both conditions, tinnitus and anxiety, significantly disrupt and impair the quality of life, they should be treated simultaneously but also individually, in order to achieve the best results for each patient and improve the quality of life. Therefore, the psychiatric evaluation should play a central role in a multidisciplinary approach in these patients.

was obtained from all individual respondents. The research was conducted according to the Declaration of Helsinki.

Conflicts of interest. The authors declare no conflict of interest. 


\section{References:}

1. Bhatt JM, Bhattacharyya N, Lin HW. Relationships between tinnitus and the prevalence of anxiety and depression. Laryngoscope 2017;127(2):466-9.

2. Landgrebe M, Azevedo A, Baguley D, Bauer C, Cacace A, Coelho C, et al. Methodological aspects of clinical trials in tinnitus: a proposal for an international standard. J Psychosom Res 2012;73(2):112-21.

3. Pattyn T, Van Den Eede F, Vanneste S, Cassiers L, Veltman D, Van De Heyning P, et al. Tinnitus and anxiety disorders: a review. Hear Res 2016;333:255-65.

4. Chen JX, Whitton JP, Parthasarathy A, Hancock KE, Polley DB. Fluctuations in Subjective Tinnitus Ratings Over Time: Implications for Clinical Research. Otol Neurotol 2020;41(9):e1167-e73.

5. Skarżyński PH, Rajchel JJ, Gos E, Dziendziel B, Kutyba J, Bieńkowska K, et al. A revised grading system for the Tinnitus Handicap Inventory based on a large clinical population. Int J Audiol 2020;59(1):61-7.

6. McKenna L, Marks EM, Hallsworth CA, Schaette $R$. Mindfulness-based cognitive therapy as a treatment for chronic tinnitus: a randomized controlled trial. Psychother Psychosom 2017;86(6):351-61.

7. Park KH, Lee SH, Koo J-W, Park HY, Lee KY, Choi YS, et al. Prevalence and associated factors of tinnitus: data from the Korean National Health and Nutrition Examination Survey 2009-2011. J Epidemiol 2014:JE20140024.

8. Baguley D, McFerran D, Hall D. Tinnitus. Lancet 2013;382(9904):1600-07.

9. Newman CW, Jacobson GP, Spitzer JB. Development of the tinnitus handicap inventory. Arch Otolaryngol Head Neck Surg 1996;122(2):143-8.

10. Liu Y-W, Cheng X, Chen B, Peng K, Ishiyama A, Fu Q-J. Effect of tinnitus and duration of deafness on sound localization and speech recognition in noise in patients with single-sided deafness. Trends Hear 2018;22:2331216518813802.

11. Mear I. Difficulties of international clinical trials: cultural adaptation of quality of life questionnaires. Health-related quality of life and patient-reported outcomes: Scientific and useful criteria Paris: Springer 2002:55-62.

12. Wild D, Grove A, Martin M, Eremenco S, McElroy $S$, Verjee-Lorenz A, et al. Principles of good practice for the translation and cultural adaptation process for patient-reported outcomes (PRO) measures: report of the ISPOR task force for translation and cultural adaptation. Value Health 2005;8(2):94-104.

13. Ortuno-Sierra J, Garcia-Velasco L, Inchausti F, Debbane M, Fonseca-Pedrero E. New approaches on the study of the psychometric properties of the STAI. Actas Esp Psiquiatr 2016;44(3):83-92.

14. Teixeira AR, Rosito LPS, Gonçalves AK, Nunes MGP, Dornelles S, Olchik MR. Tinnitus in elderly individuals: discomfort and impact in the quality of life. Int Arch Otorhinolaryngol 2017;21(1):66-71.

15. Hou S-J, Yang AC, Tsai S-J, Shen C-C, Lan T-H. Tinnitus Among Patients With Anxiety Disorder: A Nationwide Longitudinal Study. Front Psychiatry 2020;11:606.

16. Kim H-J, Lee H-J, An S-Y, Sim S, Park B, Kim SW, et al. Analysis of the prevalence and associated risk factors of tinnitus in adults. PLoS One 2015;10(5):e0127578.

17. Pavaci S, Tortorella F, Fioretti AB, Angelone AM, Di Rienzo Businco L, Lauriello M, et al. Analysis of the audiological characteristics and comorbidity in patients with chronic tinnitus. Audiol Res 2019;9(2):33-7.

18. Baigi A, Oden A, Almlid-Larsen V, Barrenäs M-L, Holgers K-M. Tinnitus in the general population with a focus on noise and stress: a public health study. Ear Hear 2011;32(6):787-9.

19. Fetoni AR, Lucidi D, De Corso E, Fiorita A, Conti G, Paludetti G. Relationship between subjective tinnitus perception and psychiatric discomfort. Int Tinnitus J 2016;20(2):76-82.

20. Lu T, Liu J-H, Li G, Xiang T, Ma Y, Zhong J, et al. Reliability and validity of the mandarin version of the tinnitus primary function questionnaire: A preliminary observational study. Medicine 2019;98(25):e16104.

21. Karaaslan Ö, Kantekin Y, Hacımusalar Y, Dağıstan H. Anxiety sensitivities, anxiety and depression levels, and personality traits of patients with chronic subjective tinnitus: a case-control study. Int J Psychiatry Clin Pract 2020;24(3):264-9.

22. Hyvärinen P, Mäkitie A, Aarnisalo AA. Self-administered domiciliary tDCS treatment for tinnitus: a double-blind sham-controlled study. PLoS One 2016;11(4):e0154286. 


\title{
Učestalost anksioznosti kod pacijenata sa hroničnim subjektivnim tinitusom
}

\author{
Ljiljana Krsmanović ${ }^{1,3}$, Siniša Šolaja ${ }^{1,3}$, Nenad Arsoviće ${ }^{2,3}$, Bojan Joksimović3,
} Zoran Dudvarski ${ }^{2,3}$, Gabrijela Šolaja ${ }^{4}$

'Univerzitetska bolnica Foča, Odeljenje za otorinolaringologiju i maksilofacijalnu hirurgiju, Republika Srpska, Bosna i Hercegovina

${ }^{2}$ Klinički centar Srbije, Klinika za otorinolaringologiju i maksilofacijalnu hirurgiju, Beograd, Srbija

${ }^{3}$ Univerzitet Istočno Sarajevo, Medicinski fakultet, Foča, Republika Srpska, Bosna i Hercegovina

${ }^{4}$ Univerzitetska bolnica Foča, Odeljenje za neurologiju, Republika Srpska, Bosna i Hercegovina

Uvod. Tinitus je percepcija zvuka u ušima u odsustvu akustične stimulacije čiji patofiziološki mehanizmi još nisu dovoljno istraženi. Kod prosečno 1-2\% ljudi negativno utiče na svakodnevne aktivnosti. Cilj naše studije bio je da se proceni učestalost anksioznosti kod pacijenata sa tinitusom.

Metode. Studija je sprovedena kao studija preseka. Učesnici su podeljeni u dve grupe, grupa od 73 pacijenta sa tinitusom (sa dve podgrupe u odnosu na dužinu trajanja tinitusa - manje od jedne godine i više od jedne godine) i kontrolna grupa od 43 pacijenta bez tinitusa. Ispitivali smo prisustvo anksioznosti uz pomoć Burnsovog upitnika za anksioznost (eng. Burns Anxiety Inventory, BAI). Kvalitet života svih pacijenata je procenjivan uz pomoć Tinitus hendikep upitnika (engl. Tinnitus Handicap Inventory, THI).

Rezultati. $U$ grupi sa tinitusom $56,2 \%$ je imalo blagi i $24,7 \%$ umereni gubitak sluha, dok je $27,7 \%$ ispitanika iz kontrolne grupe imalo blagi i 8,5\% umereni nivo oštećenja sluha. Rezultati THI pokazali su da su pacijenti sa tinitusom kraćim od jedne godine imali značajno $(p=0,002)$ viši nivo poremećaja u svakodnevnim aktivnostima u poređenju sa grupom koja je imala tinitus duže od jedne godine. Minimalnu anksioznost je imalo 30,8\% ispitanika, 26,7\% graničnu anksioznost, 17,5\% blagu anksioznost, isti procenat ispitanika umerenu, $5 \%$ tešku, dok je 2,5\% imalo ekstremnu anksioznost na osnovu BAI.

Zaključak. Anksioznost se može smatrati potencijalno značajnim modulatorima promena uočenim u moždanim strukturama kod ljudi sa tinitusom.

Ključne reči: tinitus, anksioznost, tinitus hendikep upitnik, Burnsov upitnik anksioznosti 